\title{
Eubacterium aerofaciens (Eggerth) Prévot 1938: Emendation of Description and Designation of the Neotype Strain
}

\author{
W. E. C. MOORE, ELIZABETH P. CATO, and LILLIAN V. HOLDEMAN
}

Anaerobe Laboratory, Division of Basic Sciences, College of Agriculture, Virginia Polytechnic Institute and State University, Blacksburg, Virginia 24061

\begin{abstract}
The characteristics of ATCC 25986 conform very closely to those given in the original description of Bacteroides aerofaciens Eggerth 1935 as well as to those which form the current concept of this organism. The authors propose ATCC 25986 as the neotype strain of Eubacterium aerofaciens (Eggerth) Prévot 1938 and provide an updated description of this species.
\end{abstract}

In 1935 Eggerth (2) described Bacteroides aerofaciens on the basis of 18 strains isolated from human feces. This species was included in the genus Eubacterium by Prévot in 1938 (3). None of Eggerth's original strains is extant, and it is necessary, therefore, to designate a neotype strain for this species.

\section{MATERIALS AND METHODS}

Bacterial strains. We recently isolated 46 strains from the normal flora of animals and humans: 34 from human feces (including ATCC 25986, the proposed neotype strain), four from chicken cecal contents, six from chicken large-intestinal contents, one from dog large-intestinal contents, and one from hog large-intestinal contents. Five strains were isolated from infections: two from human blood, one from human chest drainage, one from pus from a human intestinal fistula, and one from a turkey liver lesion. Two additional strains were examined from the Prévot collection. A.ll 53 strains conform closely to the substantial description of $E$. aerofaciens (B. aerofaciens) by Eggerth (2).

Methods. The methods used in the following characterization of $E$. aerofaciens have been described previously (1).

\section{RESULTS AND DISCUSSION}

The original description of $E$. aerofaciens and our observations on 53 strains are listed in Table 1.

We found the morphology to be exactly the same as described by Eggerth (2). Cells had rounded, pointed, or square ends and were arranged in chains of 2 to 10 or more elements (Fig. 1). The individuals in one chain often varied greatly in size and shape: long bacilli and cocci of various sizes succeeded each other in the chains. Cells with central swellings were common as were bent and curved rods. Chains were often twisted or knotted where several cells in the chain were bent. Cells in some cultures showed bifid or branched forms, especially in bent cells. Eggerth found metachromatic granules to be numerous in cells on glucose agar and on potato medium but less common in cells grown on blood or liver agar.

On blood agar, colonies were 1 to $2 \mathrm{~mm}$ in diameter, circular, entire to slightly scalloped, convex, translucent, grey-white, smooth, and glistening. Eggerth reported that with some strains the colonies were very tough and difficult to emulsify.

In glucose broth a turbidity developed; there was also sediment which sometimes was flocculent or stringy. With most strains the final $p \mathrm{H}$ in glucose broth (after 15 days of incubation) was 4.8. With ATCC 25986 the final $p \mathrm{H}$ was 4.9 . The temperature for optimal growth was $37 \mathrm{C}$, although some strains grew equally well at 30 or $45 \mathrm{C}$.

Products of fermentation of peptone-yeast extract-glucose broth were DL-lactic acid (2.5 to $8 \mathrm{meq} / 100 \mathrm{ml}$ ), acetic acid $(0.9$ to 2.8 $\mathrm{meq} / 100 \mathrm{ml})$, succinic acid $(0.4$ to $1 \mathrm{meq} / 100$ $\mathrm{ml})$, and formic acid $(0.2$ to $2.8 \mathrm{meq} / 100 \mathrm{ml})$. Threonine and lactate were not attacked, but pyruvate was converted to acetate and formate. Eggerth stated that none of the strains coagulated milk. However, coagulation took place when the milk cultures were heated. Under our conditions, $48 \%$ of our strains coagulated milk without heating. The neotype 
TABLE 1. Descriptions of Eubacterium aerofaciens and its neotype strain

\begin{tabular}{|c|c|c|c|}
\hline Characteristic & $\begin{array}{l}\text { Eggerth's descrip- } \\
\text { tion }^{a}\end{array}$ & $\begin{array}{l}\text { Emended descrip- } \\
\operatorname{tion}^{b}\left(\%^{+}\right)\end{array}$ & Neotype $\operatorname{strain}^{C}$ \\
\hline Anaerobic $\ldots \ldots \ldots \ldots \ldots$ & + & $(100)$ & + \\
\hline Gram-positive rod $\ldots \ldots \ldots \ldots$ & + & $(100)$ & + \\
\hline Endospores $\ldots \ldots \ldots \ldots \ldots$ & - & $(0)$ & - \\
\hline Motility $\ldots \ldots \ldots \ldots \ldots$ & - & $-\quad(0)$ & - \\
\hline Size $\ldots \ldots \ldots \ldots \ldots \ldots$ & $0.4-2 \times 0.8-5 \mu \mathrm{m}$ & $0.4-2 \times 0.8-5 \mu \mathrm{m}$ & $0.5-0.8 \times 2.4-4.7 \mu \mathrm{m}$ \\
\hline Hemolysis $\ldots \ldots \ldots \ldots \ldots \ldots$ & - & $-(19$ weak $\beta)$ & - \\
\hline Lecithinase $\ldots \ldots \ldots \ldots \ldots$ & & $-\quad(0)$ & - \\
\hline Lipase . . . . . . . . . . . & & $(0)$ & - \\
\hline Adonitol $\ldots \ldots \ldots \ldots \ldots$ & - & $(0)$ & - \\
\hline Amygdalin $\ldots \ldots \ldots \ldots \ldots \ldots$ & & (4) & - \\
\hline Arabinose $\ldots \ldots \ldots \ldots \ldots \ldots$ & - & (9) & - \\
\hline Cellobiose $\ldots \ldots \ldots \ldots \ldots \ldots$ & & $(75)$ & - \\
\hline Dextrin $\ldots \ldots \ldots \ldots \ldots$ & + & (6) & - \\
\hline Dulcitol $\ldots \ldots \ldots \ldots \ldots$ & - & $(0)$ & - \\
\hline Erythritol $\ldots \ldots \ldots \ldots \ldots \ldots$ & - & (2) & - \\
\hline Esculin $\ldots \ldots \ldots \ldots \ldots \ldots$ & + & (6) & - \\
\hline Fructose $\ldots \ldots \ldots \ldots \ldots \ldots$ & + & $(100)$ & + \\
\hline Galactose $\ldots \ldots \ldots \ldots \ldots \ldots$ & + & $(96)$ & + \\
\hline Glucose $\ldots \ldots \ldots \ldots \ldots \ldots$ & & $(100)$ & + \\
\hline Glucosamine $\ldots \ldots \ldots \ldots \ldots$ & + & & \\
\hline Glycerol $\ldots \ldots \ldots \ldots \ldots \ldots$ & - & (0) & - \\
\hline Glycogen $\ldots \ldots \ldots \ldots \ldots \ldots$ & + & (2) & - \\
\hline Inositol $\ldots \ldots \ldots \ldots \ldots \ldots \ldots$ & - & $(0)$ & - \\
\hline Inulin $\ldots \ldots \ldots \ldots \ldots \ldots$ & - & $(0)$ & - \\
\hline Lactose $\ldots \ldots \ldots \ldots \ldots \ldots$ & + & $(85)$ & + \\
\hline Maltose $\ldots \ldots \ldots \ldots \ldots \ldots$ & + & $(100)$ & + \\
\hline Mannitol $\ldots \ldots \ldots \ldots \ldots \ldots$ & - & (6) & - \\
\hline Mannose $\ldots \ldots \ldots \ldots \ldots \ldots$ & + & $(100)$ & + \\
\hline Melezitose $\ldots \ldots \ldots \ldots \ldots \ldots$ & - & (4) & - \\
\hline Melibiose $\ldots \ldots \ldots \ldots \ldots \ldots$ & & (21) & - \\
\hline Methyl-glucoside $\ldots \ldots \ldots \ldots$ & \pm & & \\
\hline Pectin $\ldots \ldots \ldots \ldots \ldots \ldots$ & & $(88)$ & + \\
\hline Raffinose $\ldots \ldots \ldots \ldots \ldots \ldots$ & - & $(25)$ & - \\
\hline Rhamnose $\ldots \ldots \ldots \ldots \ldots \ldots$ & - & $(0)$ & - \\
\hline Ribose $\ldots \ldots \ldots \ldots \ldots \ldots$ & & (4) & - \\
\hline Salicin $\ldots \ldots \ldots \ldots \ldots \ldots$ & + & (91) & + \\
\hline Sorbitol $\ldots \ldots \ldots \ldots \ldots \ldots$ & - & $(0)$ & - \\
\hline Sorbose $\ldots \ldots \ldots \ldots \ldots \ldots$ & & $(4)$ & - \\
\hline Starch $\ldots \ldots \ldots \ldots \ldots \ldots$ & \pm & $(8)$ & - \\
\hline Sucrose $\ldots \ldots \ldots \ldots \ldots$ & + & $(83)$ & + \\
\hline Trehalose $\ldots \ldots \ldots \ldots \ldots \ldots$ & + & (17) & - \\
\hline Xylose $\ldots \ldots \ldots \ldots \ldots \ldots$ & - & $(8)$ & - \\
\hline Starch hydrolyzed $\ldots \ldots \ldots \ldots$ & & (4) & - \\
\hline Hippurate hydrolyzed $\ldots \ldots \ldots$ & & (4) & - \\
\hline Gelatin liquefied $\ldots \ldots \ldots \ldots$ & - & $\pm \quad(43$ weak $)$ & - \\
\hline Esculin hydrolyzed $\ldots \ldots \ldots \ldots$ & & $\pm \quad(66)$ & + \\
\hline Acetylmethylcarbinol $\ldots \ldots \ldots$ & & (11) & - \\
\hline Gas $\ldots \ldots \ldots \ldots \ldots \ldots \ldots$ & + & $(87)$ & + \\
\hline $\mathrm{H}_{2} \mathrm{~S} \ldots \ldots \ldots \ldots \ldots \ldots \ldots \ldots \ldots \ldots \ldots$ & - & $(0)$ & - \\
\hline Milk acid $\ldots \ldots \ldots \ldots \ldots \ldots$ & + & $(89)$ & + \\
\hline Coagulated egg white digested $\ldots$. & - & & \\
\hline Meat digested $\ldots \ldots \ldots \ldots \ldots \ldots$ & & $(0)$ & - \\
\hline
\end{tabular}


TABLE 1.-(Continued)

\begin{tabular}{|c|c|c|c|}
\hline Characteristic & $\begin{array}{l}\text { Eggerth's descrip- } \\
\text { tion }^{a}\end{array}$ & $\begin{array}{l}\text { Emended descrip- } \\
\operatorname{tion}^{b}(\%+)\end{array}$ & Neotype strain $c$ \\
\hline $\begin{array}{l}\text { Nitrate reduced } \ldots \ldots \ldots \ldots \ldots \ldots \\
\text { Neutral red reduced } \ldots \ldots \ldots \ldots \ldots \\
\text { Catalase } \ldots \ldots \ldots \ldots \ldots \ldots \ldots \ldots \ldots \\
\text { Indole } \ldots \ldots \ldots \ldots \ldots \ldots \ldots \ldots \\
\mathrm{NH}_{3} \ldots \ldots \ldots \ldots \ldots \ldots \ldots \\
\text { Growth in } 20 \% \text { bile } \ldots \ldots \ldots \ldots \ldots\end{array}$ & - & $\begin{array}{rr}- & (0) \\
\pm & (89) \\
- & (0) \\
- & (0) \\
\pm & (79) \\
+ & (94)\end{array}$ & $\begin{array}{l}- \\
+ \\
- \\
- \\
+ \\
+\end{array}$ \\
\hline
\end{tabular}

${ }^{a}$ Eggerth's original description (2).

$b$ Emended species description by Moore, Cato, and Holdeman on the basis of 53 strains.

${ }^{c}$ ATCC 25986; VPI (Virginia Poly technic Institute) 1003.

strain did not. As reported by Eggerth, gelatin was not liquefied, although melting time of 23:53 incubated and chilled cultures was less than half of that of uninoculated control tubes. Growth was variable in media with $6.5 \% \mathrm{NaCl}$ or at $p \mathrm{H} \mathrm{8.6.} \mathrm{The} \mathrm{neotype} \mathrm{strain} \mathrm{does} \mathrm{grow} \mathrm{at}$ $p \mathrm{H}$ 8.6.

The cell walls of 36 strains, including the neotype strain, were shown by C. S. Cummins (personal communication) to contain no diaminopimelic acid.

Eggerth reported that none of the strains was pathogenic for white mice. However, several produced subcutaneous abscesses when injected into rabbits; the abscesses healed promptly when incised, more slowly otherwise. The organisms were numerous in the pus. Single, slender forms, shorter diplobacilli, and cells with central swellings were present.

Our results agree well with those reported by Eggerth (2) for this organism. The important discrepancies concern the fermentation of dextrin and trehalose. It is quite possible that the composition or purity of these two substrates differed between the two laboratories.

Characteristics which qualify E. aerofaciens as a member of the genus Eubacterium Prévot. This species is a member of the genus Eubacterium because it is a gram-positive, obligately anaerobic, nonsporeforming rod which does not produce propionic acid as a major acid product (Propionibacterium); lactic as a sole major acid product (Lactobacillus); large amounts of succinic (in the presence of $\mathrm{CO}_{2}$ ) and lactic acids, sometimes with acetic and formic acids (Actinomyces); or acetic and lactic acids (acetic $\geq$ lactic), with or without formic, as sole major acid products (Bifidobacterium).

Characteristics which constitute the basic concept of the species Eubacterium aerofaciens and differentiate it from other species of Eubacterium. Although there are other organisms with a morphology similar to that of $E$. aerofaciens which might be confused with this

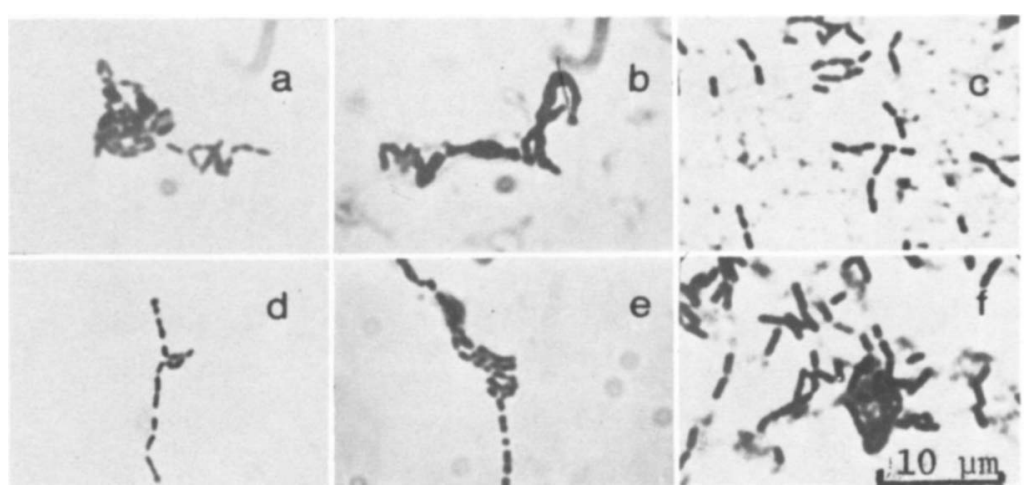

FIG. 1. Cellular morphology of Eubacterium aerofaciens. Gram stains of 24-hr broth cultures. a, ATCC 25986, peptone-yeast extract-glucose; b, ATCC 25986, peptone-yeast extract-glucose; $c$, ATCC 25986, modified rumen fluid-glucose-cellobiose-broth; $d$, VPI (Virginia Polytechnic Institute) 3938, peptone-yeast extract; $e, V P I$ 3938 , peptone-yeast extract; $f$, VPI 3938 , modified rumen fluid-glucose-cellobiose-broth. 
species, the pattern of substrates attacked, the absence of complete gelatin liquefaction, the production of acetic and lactic acids as major products and succinic acid as a moderate product (usually with moderate amounts of formic acid), and the absence of indole production distinguish this species from other members of the genus.

Designation of the neotype strain of $\mathbf{E}$. aerofaciens. As shown in Table 1, ATCC 25986 (VPI 1003, isolated from human feces) possesses characters which are in close agreement not only with those given in the original description of Bacteroides aerofaciens by Eggerth but also with those in the updated description of this organism presented here. ATCC 25986 is therefore designated as the neotype strain of Eubacterium aerofaciens (Eggerth) Prévot.

\section{ACKNOWLEDGMENTS}

We gratefully acknowledge the assistance of Lorna B. Pais and Karen L. Schmoker.

This investigation was supported by Public Health Service grant no. GM 14604 from the National Institute of General Medical Sciences.

\section{LITERATURE CITED}

1. Anaerobe Laboratory, Virginia Polytechnic Institute and State University. 1970. Outline of Clinical Methods in Anaerobic Bacteriology, 2nd rev. Blacksburg, Va.

2. Eggerth, A. H. 1935. The gram-positive non-sporebearing anaerobic bacilli of human feces. J. Bacteriol. 30:277-299.

3. Prévot, A.-R. 1938. Études de systématique bactérienne. III. Invalidité du genre Bacteroides Castellani et Chalmers. Démembrement et reclassification. Ann. Inst. Pasteur (Paris) 60:285-307. 